\title{
SELECTION OF STUDENT NURSES AT BAFOKENG NURSING COLLEGE
}

\author{
G. Setsoe
}

\begin{abstract}
Bafokeng Nursing College is a privately owned institution situated at the Impala Mines in Bophuthatswana. It selects and trains student nurses from all parts of Southern Africa in the comprehensive four-year course who at qualifying are free to work for Genmin or anywhere else in the country. The College is affiliated to Mectunsa in offering the four-year comprehensive course. Selection is limited because of limited facilities.
\end{abstract}

The old selection process was evaluated in 1985 and the new selection process started functioning in 1986 when the new course was offered for the first time at the College.

With the new selection process, the drop-out rate is very low, the pass rate has improved and the quality of nursing care is improving.

\section{Abstrak}

Die Bafokeng Kollege van verpleging is 'n privaat instansie wat gele ëis in Bophuthatswana naby die Impals myn. Student verpleegkundiges wat vanuit die hele Suidelike Afrika gekies word, word opgelei. Na voltooing van die vierjaar omvattende kursus, kan hulle vir Genmin of enige werkgewer in die land werk. Die kollege is aan Medunsa verbonde met betrckking tot die aanbieding van die omvattende vier jaar kursus. Weens beperke fasilitcite, word ' $n$ beperkte getal studente gekeur.

Die ou keurings proses is in 1985 gecvalueer en die huwe proses het in 1986 begin toe die nuwe kursus vir die eerste keer by die Kollege aangebied is.

Met die nuwe keurings proses is die uitvalsyfer baie laag, die slaag-syfer her verbeter en die kwaliteit van verpleegsorg word steeds beter.

\section{BACKGROUND INFORMATION}

The selection process at Bafokeng nursing College has been in existence since the training of nurses started in the 1970s. All applicants who had a matric exemption were called for an interview. The interview was not structured and was conducted by a selection committee composed of the Chief Medical Officer, Chief Nursing Services Manager, College Principal, Vice-Principal, and one of the tutors. Candidates were asked to write a psychological test that was totally unrelated to nursing. The interview was not necessarily able to recruit students who have realistic expectations about nursing. Some of the students resigned quickly from nursing because of one or more of the following reasons:-
- Immaturity - most of the younger students who resigned probably lacked a sense of responsibility or were committed to their own wellbeing rather than to the patients.

These were students who were not mature enough to cope with irritations in the situation and felt overwhelmed. Lack of emotional self-control was a sign of immaturity observed in some students who resigned. As the students are all male, dropping out of the course due to pregnancy is not a problem as it is in other nursing colleges.

Even though the reasons for resignation from the basic nursing course were many and varied, the rate in general was not as disappointing as in other nursing colleges in the country.

With the advent of the four-year comprehensive course which is academically and professionally demanding it became necessary to look deeper into the selection process. The interview was now focused on recruiting and selecting nursing students in particular and not any intellectually capable matriculants.

The previous selection process was not geared towards black South African students. It did not adequately expose the previous life experiences and ambitions of black South Africans as regards nursing as a first-career choice.

To avoid previous mistakes, the Human Sciences Research Council (HSRC) was approached with the interview schedule and asked to assist with restructuring of a new selection process that would be able to identify black male Southern African students who would be able to cope with the demands of the four-year comprehensive course. expectations were not in line with the true nature of the work. Some were not committed to nursing as a career.

* Poor interpersonal relations - some students were not responsive or warmhearted as the profession demands. They did not feel comfortable in dealing with people. Some did not react positively to conflict.

* Poor stress tolerance - some students who resigned were emotionally unstable and lacked high tolerance for emotionally demanding situations. Others lacked good control over their anxieties.
The College is offering only the four year course and wishes to recruit young men with the following characteristics:-

* who possess a good matric pass and a sound high school education i.e. matric exemption with aggregrate symbol $E$ and above.

* whose intellectual ability ranges from average to excellent.

* who have received proper career guidance.

* who have been throughly grounded in learning and studying skills.

- who have a good mastery and use of English, which is their medium of instruction. 
All the above mentioned aspects are assessed by the selection committee during a panel interview.

\section{INTRODUCTION}

The system of nursing education has been revolutionalised to such an extent that entry into professional nursing constitutes extensive preparation through a comprehensive four-year Diploma course which is offered at Nursing Colleges and Universities. Therefore, it is important to ensure that students selected for the comprehensive four-year course have successful results in matric, have realistic expectations about nursing, and are well-motivated to follow nursing as a career. Candidates who apply for the comprehensive four-year course at the College are subjected to a selection process. In this text, the selection process at this College is explained in detail.

\section{SELECTION METIIOD}

The following steps are followed in the selection of student nurses at the College:

- The use of the Swedish Rating Scale on matric results of all applicants with matric exemption.

- The use of application forms to find more information on the candidate. Application forms are only sent to candidates whose matric results are above the cut-off point prescribed for that particular year

* Writing of essays to evaluate language, realism of career expectations and motivation.

- A panel interview to further evaluate the candidate's general intelligence, competence in English, personal cleanliness, maturity, interpersonal relations, stress tolerance and initiative.

To complete the last two steps of the process, candidates are booked for two days at the College. The first day on arrival, they write the essays which are evaluated on the same day; the second day is for the panel interview.

It was not easy to structure a selection process for recruitment of black nursing students in Southern Africa if the weaknesses and short-comings of the general education system for blacks are considered. Bantu education has a ripple effect on the quality of nursing education and training for Blacks and on the quality and quantity of Black student nurses (Mashaba, 1986).

The recruitment of prospective student nurses is undermined by the fact that pupils lack career guidance in respect of nursing. Many of those who are admitted to the course, got there more by chance than by informed intelligent choice. Many more people are ignorant of what nursing is all about and especially, as it is practised in the mines.

In the selection process, care should be taken to recruit people with love and the potential to be good nurses, and avoid 'wrong' candidates who only possess intellectual capabilities, or happen to be related to senior nursing or medical personnel.
The high cost of student training necessitates careful selection of students in order to minimise student dropout (Kitsa, 1990).

\section{SELECTION PROCESS}

\section{Use of the Swedish rating scale:}

Selection of prospective student nurses at Bafokeng Nursing College is based not only on the Std 10 certificates, but also on the average symbol obtained at the Std 10 examinations, and the symbols obtained in Biology, English, and Science subjects. Even though the failure rate at Sid 10 is high, the College can afford to be selective in terms of good symbols because it receives over 1500 applications per year for about 25 posts. The College does not just take what comes its way and the scope of recruitment is restricted to the most deserving candidates. The Swedish rating scale (Table 1), is used to reduce the number of applications to managable levels. The cut-off point is 3.5 points so that only about about 40 or so candidates can be interviewed for the posts. The cut-off point is kept high because it would only be fair to give an equal chance to the most intellectually capable candidates in the interview. The Swedish rating scale, therefore, selects the most intellectually capable candidates but not all intellectually capable students have the capacity to become very good nurses, hence the essays and the panel interview.

Table 1

Swedish Rating Scale

as used at Bafokeng Nursing College

\begin{tabular}{|c|c|c|}
\hline \multicolumn{1}{c|}{} & HG & SG \\
\hline$A$ & 8 & 6 \\
\hline$B$ & 7 & 5 \\
\hline$C$ & 6 & 4 \\
\hline$D$ & 5 & 3 \\
\hline$E$ & 4 & 2 \\
\hline$F$ & 3 & 1 \\
\hline$G$ & 0 & 0 \\
\hline$H$ & 0 & 0 \\
\hline
\end{tabular}

Double Marks are awerded for:

Maths

Biology

Physical Science

English ( $D$ and above only)

(For both Higher and Standard Grade)

\section{APPLICATION FORMS}

Application forms are sent to candidates who have scored $\mathbf{3 5}$ or more in the Swedish rating and have one Science subject eg. Biology, Mathematics, or Physical Science, and English.

Application forms are used to obtain additional information such as personal data, educational qualifications, employment record, medical and/or physical defects from the candidate.

This means that applicalion forms cannot be sent to a candidate who has obtained less than 35 in the Swedish rating. A letter is written to such a candidate informing him why the application was rejected and he is advised of alternatives that he may follow. Certified copies of matric certificate, birth certificate, testimonials and two black and white passport photographs, are asked to be sent with the completed application forms for the application to be considered.

\section{THE ESSAYS}

The candidates who sent back the application forms and necessary documents are called for an interview on specific dates. Before the interview, they are requested to write short essays which are related to what will be asked in the interview. (Table 2)

\section{Table 2}

\section{Dimenslons on which} Essays are evaluated

\begin{tabular}{l} 
LANGUAGE: \\
Grammatically correct \\
Spelling \\
Richness of expression \\
Clarity of communication \\
\hline REALISM OF CAREER \\
EXPECTATIONS: \\
Does the candidate's understanding of \\
a nurse's duties appear to be: \\
inadequate or unrealistic \\
$\quad$ acceptable \\
$\quad$ show more than average depth \\
$\quad$ and perception. \\
MOTIVATION: \\
Is the candidate motivated to do nursing \\
for reasons that are intrinsic to the work \\
itself?
\end{tabular}

\section{TIIE INTERVIEW}

\section{The Selection Committee:}

The interview of prospective student nurses at the College is conducted by a selection committee, which is made up of the following 5 members:-

* The College Principal;

* The Chief Nursing Services Manager from the Hospital;

- A lecturer from MEDUNSA (to which the College is affiliated);

* One of the tutors;

* Respresentative from the Manpower Department (specifically concerned with recruitment and selection of workers).

The purpose of the Interview:

The purpose of the interview is to give a fair and equal chance to all qualifying candidates, to expose their previous life experiences, their ambitions about their future career, and what they wish to achieve, in order to be considered for selection and training. Structured questions are asked, by the panel with the aim of exposing the candidate's:

* General intelligence: the candidate should possess the intellectual competence for the training course material.

* Competence in English: the candidate should be able to comprehend written or 
spoken English and make himself understood.

Personal Cleanliness: observation is made on whether the candidate appears sufficiently neat and clean to meet the standards of hygiene required in nursing. Maturity: some questions relate to the candidate's sense of responsibility, commitment to the patient's rather than his own well-being, emotional self-control and his ability to withstand irritations in the situation that might overwhelm him.

Interpersonal relations: nursing needs people who are socially responsive, warmhearted, comfortable in dealing with people and react positively to conflict.

Stress tolerance: the mining industry might pose a strange environment and having to deal with seriously ill and dying patients would need a person who is emotionally stable, with good control over his anxieties and with a high tolerance for emotionally demanding situations.

" Initiative: nursing does nol need people who are pushed into it because they performed badly at matric, are unable to go to University because of poor matric results, or are forced into it because parents insist on their child beonming a nurse. Nursing needs people who are self-motivating, self-reliant and decisive about their career choice. We do not need people who come to nursing as a last resort ie, when they had failed to obtain admission in other fields of study.

Motivation: the choice of nursing as a career should be done with care and intelligence. In this regard, job expectations should be in line with the true nature of the work. The candidate must show evidence of his commitment to nursing as a career and his reasons for this career choice must be acceptable to the selection commiltce.

In the interview, all candidates are asked asically the same questions and an evaluation of the above-mentioned factors is made using a rating scale. The points in the rating scale are zounted and candidates with the highest points are considered for selection. After the interview, the candidates are released to go home and candidates are informed of the results of the selection process by post probably within a week or two.

\section{EFFECTIVENESS OF TIIE SELECTION PROCESS}

A total number of 115 students were selected over five years (1986-1990) and only nine have resigned. That represents an overall attrition rate of $7,8 \%$ over 5 years

Of the nine who dropped out of the course, four (4) resigned for personal reasons, one (1) was forced to resign for disciplinary reasons, and the other four (4) could not cope with the academic demands of the course.

$\Lambda$ study was made on the rating forms of all nine students who dropped out of the course and it was interesting to note that eight of them were rated poorly on stress tolerance during the interview. The student who was forced to resign for disciplinary reasons was rated positively on stress tolcrance!

The selection process seemed able to select students who are committed to nursing as a career. Since the new selection process was started, discipline amongst student nurses has improved tremendously. Absenteeism, disobedience, negligence and disorderly behaviour have decreased greatly. One could attribute this to the fact that students understand what they are going to achieve after four years.

Most students are assertive and are able to accept leadership roles with ease.

\section{CONCLUSION}

The comprehensive four-year course which combines general nursing, psychiatric nursing, community health nursing and midwifery, constitutes entry into professional nursing. For this reason, it is important to select students who are academically capable of undertaking the course. The task of the course is to:

- Offer a realistic preparation of the student to meet the national heal th needs while keeping abreast of modern developments;

- Equip the student nurse with knowledge, skills and professional and social attitudes to enable him to render quality care;

- Laying a broad and firm foundation to enable the qualified nurse to rise and soar to dizzy heights of academic and professional excellence;

- Attain the Nursing Council objectives to enable the qualified nurse to register with this body;

- produce enough qualified professional nurses to meet health needs of patients/clients (Basson \& Botes, 1989).

Table 3

Effectiveness of the Selection Process

\begin{tabular}{|l|c|c|c|c|c|}
\hline \multicolumn{1}{|c|}{ YEAR GROUPS } & $4 / 86$ & $4 / 87$ & $4 / 88$ & $4 / 89$ & $4 / 90$ \\
\hline Total No. selected & 25 & 25 & 25 & 20 & 20 \\
\hline Total No. resigned/dropped out & 2 & 3 & 4 & 0 & 0 \\
\hline Total No. remaining/completed & 23 & 22 & 20 & 20 & 20 \\
\hline Attrition rate & $8 \%$ & $12 \%$ & $16,7 \%$ & $0 \%$ & $0 \%$ \\
\hline Retention rate & $92 \%$ & $88 \%$ & $83,3 \%$ & $100 \%$ & $100 \%$ \\
\hline
\end{tabular}

* One student died in his first year of study.

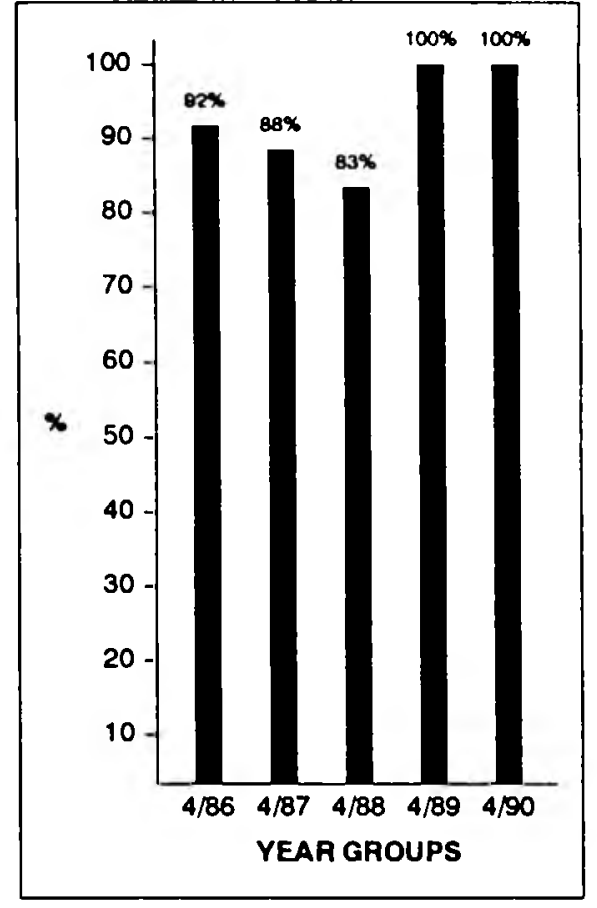

\section{Figure 1 \\ Chart to show number of students completed or remaining on the course (1986 - 1990)}

The selection process at the College certainly provides guidelines on how future nurses can be selected from a large group of applicants. It was a good learning experience in which improvements can be made to suit different health and/or educational institutions.

Since the introduction of this selection process, the altrition rate has dropped, the pass rate improved markedly, and the quality of nursing care has improved at hospitals and clinics served by our students. Gone are the days when candidates who obtained the worst results in matric were pushed into nursing and teaching. Nursing and teaching are now competing with Universities for the candidates with the best matric passes. Aftcrall, who needs half-baked matricultants for fully-fledged professions!

\section{REFERENCES}

BASSON, A AND BOTES, A 1989. Die gebruik van die Sweedse skaal by die keuring van Verpleegkunde studente aan die Randse Afrikaanse Universiteit. Curationis 3-4, 51-56

KJTSA, A. 1990 Annual Report: Bafokeng Nursing College.

MASHABA, T.G. 1986. Implications of the education system for Blacks in Nursing Education. Curationis 3, 1-4.

\section{ACKNOWLEDGEMENT}

Acknowledgement is expressed to Mrs Linda Crear for typing this script

Geoffrey Selsoe R.N.; R.T.; RCHN;BA CUR (UNISA)

Tutor: Bafokeng Nursing College 